\title{
Sustainability indicators of land-use planning for medium-sized cities: a case study of Nigde, Turkey
}

\author{
A. Akbulut ${ }^{1}$ \& Ö. Özçevik ${ }^{2}$ \\ ${ }^{1}$ Department of City and Regional Planning, Nigde University, Turkey \\ ${ }^{2}$ Department of City and Regional Planning, \\ Istanbul Technical University, Turkey
}

\begin{abstract}
In this paper, sustainable development, proposed as a global objective, was studied with the determination of optimal city size, using a medium-sized city to achieve this. Land-use planning, managed by local governments, can be the most effective tool for the planning of medium-sized cities. In light of this information, the aim of this study is to examine the importance of having an awareness degree about the subject of local governments, for providing the measurability and applicability of sustainable development indicators by way of land-use planning. Our hypothesis is that the medium-sized cities' land-use plans can create progress related to the local goverments' knowledge, perceptions and expectations about sustainable development indicators. The case study area, Nigde City Centre, is a medium-sized city with a population of approximately 110,000 people and is located in the historical Cappadocia territory of the Central Anatolia Region of Turkey. In the first phase of the study, the current upper scale plans were evaluated by connecting them to the sustainable development indicators for Nigde. In the second phase of the study, local government authorities' knowledge, perceptions and expectations about sustainable development in land-use planning were measured by the semi-structured in-depth interview method. According to the findings of the research, Nigde has inadequate access to sustainable development indicators of land-use plans. And this inadequacy is seen at the city's local authorities' level of perception, knowledge and expectations about sustainable development indicators.

Keywords: sustainable development, sustainable development indicators, landuse planning, medium-sized cities, local government, Nigde, Turkey, Cappadocia.
\end{abstract}




\section{Introduction}

The World Bank issued a report in 2012 stating that for the first time, more than half the world's population lived in urban areas. This was brought about by rapid population growth as the cause for global urban problems, particularly in developing or least developed countries.

The medium- and small-sized cities of these countries were those that were mostly affected. However, large-scale problems of these cities often do not have the capacity to cope with the rapid growth. Therefore, based on the principles of sustainable development, participatory, investments, initiatives and programming that are optimal to urban land planning. To overcome these challenges that would help the cities, the main ideas that are discussed are as follows - this information directs the work in the light of current problems:

- Population growth rate - adequacy of natural resources - consumption habits

- Unsustainable land-use practices

- Medium-sized cities, the inability to assess the potential of sustainable urban development

- Medium-sized vehicles in urban planning and sustainable urban development by local governments has been identified as the inability to appoint the right people to deal with the problems

The following problems request city planning:

- The implementation of sustainable land-use planning process

- Medium-sized urban land-use planning, sustainable development indicators to be included in the planning process of the local government

- Local government officials and employees' level of knowledge about sustainable urban development can be increased with the proper applications

With the hypotheses of this study, sustainable land-use planning in the process of development indicators measure responsible for the implementation of local governments.

This perception of sustainable development indicators, knowledge, expectation, urban issues and with the implementation of sustainable development indicators are in a relationship and being in the right proportion.

Work frequently used in "land-use planning" is implemented by the Food and Agriculture Organization (FAO) [2]. According to this definition, soil and water resources, economic and social conditions are to meet the needs of present and future generations the optimum use is a systematic assessment of the decisions taken. In terms of an urban planning perspective; "Human society uses the resources of the land, or where its land-use planning is already done consciously or unconsciously", advocating the opinions of Chapin and Kaiser [3], land-use planning and production-oriented planning is not only about the Earth's resources but it's also about using the concepts of protection, especially when it regulates community, sharing, communication and other concepts. 
Sustainable development, when considering the relationship with landuse planning, is to Godschalk [4] the implementation of sustainable urban development in important and controversial areas, and is one of the main tools.

He states that it also stems from the contradictions of sustainability which is its inherent characteristic. The land-use planning process, including the applicability and validity of the human element, can be the first point of saving the beginning as the first point of the process.

According to Zimmermann [5], a land-use planning document consists of five main steps. These are: the identification of the main indicators; the creation of information systems; problem analysis and specification of objectives; policies/plans for development; and action planning. Examining existing models of urban development, land-use planning is used to ensure urban development while trying to develop a set of indicators and aims [6]. This indicator set, to-date, comprises easily understandable data and can be collected to ensure resources are evaluated. An indicator shows that the system works by assessing how well it can be characterized as a synthesized criteria [7]. Within the framework of sustainable development in land-use planning, work for different organizations and different sets of indicators have been established [8]. Locally produced measurable values with universal indicator sets work with these sustainable urban developments and the existing barriers in order to determine its potential. This is recognized as a very important element.

All societies in this historical process, with various different constant factors, have entered into the quest for the ideal city size [9]. Working out, in advance, a sustainable development plan for these assumptions for medium-sized cities has a lot of potential. Flow to the metropolitan cities in the 21 st century can be overtaken, and sustainable urban development, which could alleviate the speed of this process, can be implemented with concrete policy needs - an urban scale is manifested by the Rochester Conservation report [10]. The importance of medium-sized cities and towns increases day by day, especially in developing countries and Turkey in this context has "key cities" and is expected to develop [9]. The primary agency responsible for the administration of the city is the local authorities, this means they are responsible for providing land-use planning processes and for realizing the importance of these sustainable development indicators.

\section{General analysis of Nigde province}

Turkey is officially accepted as a medium-sized city, although there is no generally accepted classification [11]: 50,000 increase core/central city and its surrounding settlement within the whole city of 100,000 for an area population of 750,000 meters of an urban area population. From this range placement, it is a clump of a medium-sized urban area that can be described as going in the right direction. According to this standard in the Central Anatolia Region of Turkey (see Fig. 1) located in the province of Cappadocia, the following urban population of about 158,000 of a total of 340,000 had these studies conducted in the Nigde province. 


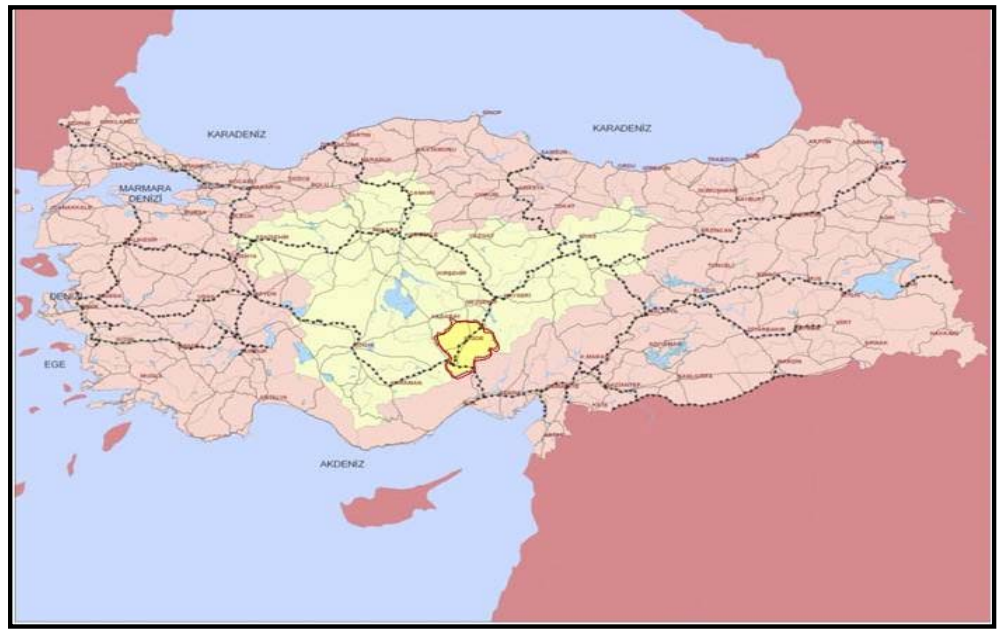

Figure 1: Location within the province of Nigde in Turkey. Source: Nigde Municipality, 2011.

Construction of this urban analysis could be summarized as; provincial town with a population of 105,702 people, the majority of them with $47 \%$ of those on the plateau, with a continental climate, with rich geothermal resources, at the 4th threat level of earthquake zone, which has little arable land, but it makes individual efforts convenient, especially in horticulture.

In the agricultural sector, which employs $73 \%$ of the employees who migrated to neighbouring provinces, the literacy rate in the regions where educational standards are high according to the health service, is inadequate. Based on year 7000BC historical values, they can't assess the current maps which, unfortunately, are not digital, and so the current zoning plan did not proceed on the basis that in 1981 identity and vision were not connected to it, thus, emerging as a mediumsized city in Anatolia (see Figs 2 and 3).

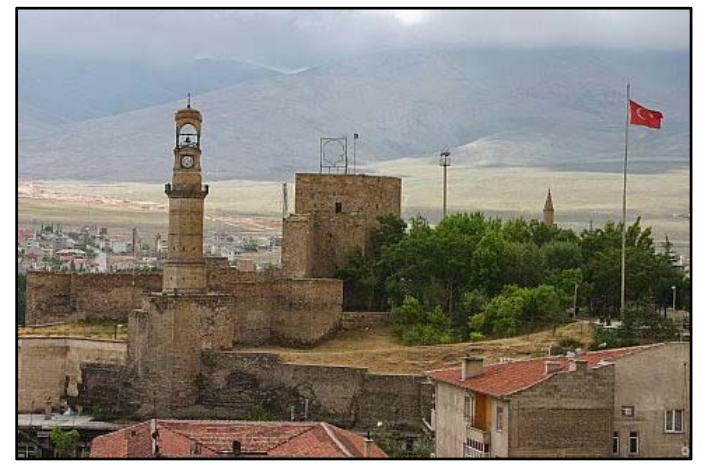

Figure 2: The view from the castle in the historic center of Nigde. Source: A. Akbulut, 2013 (author). 


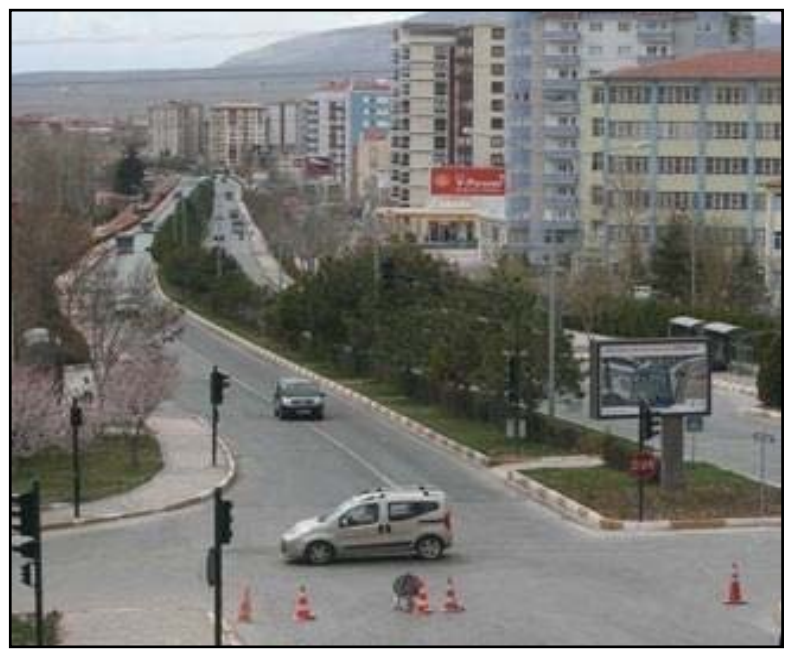

Figure 3: The appearance of the area of the housing development site. Source: A. Akbulut, 2013 (author).

\section{Methods}

The methodology applied in this study area consists of two stages. The first stage: forming the basis of the hypothesis, Nigde's set of indicators for sustainable development of the province's current plans create these values The second stage: a set of indicators for which local government officials to interpret.

In literature reviews, on topics such as sustainable development indicators or field training of personal engaged in the studying, many variables have been observed in these structures.

Therefore, the original set for Nigde is formed. Under six main themes, in 63 indicators of sustainable development, is a multi-faceted attempt to handle the situation (see Tables 1-6). In this research, an in-depth, semi-structured interview technique with Nigde's municipality was set up with 17 local government officials. Also, the local management of medium-sized cities, where there is a problem of qualified personnel managers for all administrative units, has also been selected to participate for in-depth interviews. The participation rate is currently 100\%. A survey conducted in August 2010 [12], from the United States - Illinois, Wisconsin, in the states of Georgia and South Carolina - worked together with their local governments. This has been applied in more than 1000 administrative public institutions responsible for a sustainable future. Multiple-choice questions were used, as well as a content analysis method, with very open-ended questions. The main objective of the content analysis of the collected data was to explain the concepts and relationships. Content analysis is basically the process of looking at similar data in the context of specific concepts and themes, and bringing this data together and organizing it in a format that can be understood by the reader to interpret [13]. 
Table 1: Agricultural and food indicators. Source: adapted from [7, 15, 17].

\begin{tabular}{|c|c|c|}
\hline \multirow{8}{*}{$\begin{array}{l}\text { Agriculture } \\
\text { and food }\end{array}$} & \multirow{5}{*}{ Agriculture } & Indicator \\
\hline & & $\begin{array}{l}\text { The amount of land under organic farming- } \\
\text { certified }\end{array}$ \\
\hline & & $\begin{array}{l}\text { By-year percentage change of the amount of } \\
\text { agricultural land }\end{array}$ \\
\hline & & $\begin{array}{l}\text { By-year percentage change of the number of } \\
\text { farmers }\end{array}$ \\
\hline & & $\begin{array}{l}\text { Agricultural income per household in the study } \\
\text { area-year percentage change compared }\end{array}$ \\
\hline & \multirow{3}{*}{ Food } & $\begin{array}{l}\text { Agriculture-based, non-polluting number of } \\
\text { industrial companies according to year of change }\end{array}$ \\
\hline & & $\begin{array}{l}\text { Farm and/or existence of vocational high school } \\
\text { graduates in the number of students }\end{array}$ \\
\hline & & $\begin{array}{l}\text { Number of enterprises engages in the production } \\
\text { of local food brand and year of change }\end{array}$ \\
\hline
\end{tabular}

Table 2: Energy and waste indicators. Source: adapted from [14, 15, 18].

\begin{tabular}{|c|c|c|}
\hline \multirow{7}{*}{$\begin{array}{l}\text { Energy } \\
\text { and } \\
\text { waste }\end{array}$} & \multirow{3}{*}{ Energy } & Indicator \\
\hline & & Per-person annual electrical energy consumption \\
\hline & & Identify potential work-renewable energy sources \\
\hline & \multirow{4}{*}{ Waste } & $\begin{array}{l}\text { Renewable energy sources and its place in total energy } \\
\text { production }\end{array}$ \\
\hline & & Waste management plan assets, the target year period \\
\hline & & $\begin{array}{l}\text { Solid waste disposal and treatment plant has an annual } \\
\text { capacity }\end{array}$ \\
\hline & & The amount of annual household water consumption per-year \\
\hline
\end{tabular}

Table 3: Transportation and infrastructure indicators. Source: adapted from $[7,15,18]$.

\begin{tabular}{|c|c|c|}
\hline \multirow{7}{*}{$\begin{array}{l}\text { Transportation } \\
\quad \text { and } \\
\text { infrastructure }\end{array}$} & \multirow{4}{*}{ Transportation } & Indicator \\
\hline & & $\begin{array}{l}\text { The number of administrative buildings } \\
\text { disabled access cannot be provided }\end{array}$ \\
\hline & & Bike path and length of existence \\
\hline & & $\begin{array}{l}\text { The number and capacity of parking in } \\
\text { the city center }\end{array}$ \\
\hline & \multirow{3}{*}{ Infrastructure } & $\begin{array}{l}\text { Alternative environmentally friendly } \\
\text { modes of transportation assets and } \\
\text { number of }\end{array}$ \\
\hline & & $\begin{array}{l}\text { Inaccessible by public transport modes- } \\
\text { site(neighborhood, village) number }\end{array}$ \\
\hline & & $\begin{array}{l}\text { Non-paved road in the province of } \\
\text { transportation provided by the presence of } \\
\text { settlements and link length }\end{array}$ \\
\hline
\end{tabular}


Table 4: Land-use indicators. Source: adapted from [14, 15, 18$]$.

\begin{tabular}{|c|c|c|}
\hline \multirow{13}{*}{$\begin{array}{c}\text { Land } \\
\text { use }\end{array}$} & & Indicator \\
\hline & Plans & Upper and lower scale plans to fit with each other \\
\hline & Population & Within the boundaries of the area population density \\
\hline & \multirow{10}{*}{$\begin{array}{l}\text { Reinforcement } \\
\text { areas }\end{array}$} & $1^{\text {st }}$ stage of per capita health field \\
\hline & & $2^{\text {nd }}$ stage of per capita health field \\
\hline & & $3^{\text {rd }}$ of per capita health field \\
\hline & & Active green space per capita \\
\hline & & Administrative facility area per capita \\
\hline & & Per-person trade area \\
\hline & & Primary education area per capita \\
\hline & & Secondary education area per capita \\
\hline & & Socio-cultural facilities per capita \\
\hline & & Religious facilities per capita \\
\hline
\end{tabular}

Table 5: Environmental health indicators. Source: adapted from [14-16].

\begin{tabular}{|c|c|c|}
\hline & & Indicator \\
\hline & & Children's playground \\
\hline & & Park \\
\hline & & Neighborhood park \\
\hline & green space & Area park \\
\hline & & Sports area \\
\hline & & Promenade area \\
\hline & $\begin{array}{l}\text { Ouality of } \\
\text { urban green } \\
\text { space }\end{array}$ & $\begin{array}{l}\text { Individuals' level of satisfaction with the quality of } \\
\text { urban green space }\end{array}$ \\
\hline & $\begin{array}{l}\text { Water } \\
\text { quality }\end{array}$ & Potable water reserves on population ratio \\
\hline & & $\begin{array}{l}\text { Potable mains water consumption rate by the number } \\
\text { of households }\end{array}$ \\
\hline Environmental & & $\begin{array}{l}\text { Within the boundaries of the study area ready for the } \\
\text { amount of water consumed per person }\end{array}$ \\
\hline health & & $\begin{array}{l}\text { Within the boundaries of the study area and population } \\
\text { according to the treatment plant capacity adequacy }\end{array}$ \\
\hline & & $\begin{array}{l}\text { According to the results by year-emission } \\
\text { measurements of airborne emissions (PM10, } \mathrm{SO}_{2} \text {, } \\
\mathrm{NO}_{2}, \mathrm{CO}_{2} \text { ) exchange }\end{array}$ \\
\hline & Air quality & $\begin{array}{l}\text { Use the filters on chimneys of industrial } \\
\text { organizations-rate change over the years }\end{array}$ \\
\hline & & $\begin{array}{l}\text { Charcoal, sawdust, etc. polluting fuels natural gas } \\
\text { usage rate per household and so on the ratio of non- } \\
\text { polluting fuels }\end{array}$ \\
\hline & Natural & $\begin{array}{l}\text { For the protection of natural values of the area created } \\
\text { asset management plan }\end{array}$ \\
\hline & $\begin{array}{l}\text { resources } \\
\text { and }\end{array}$ & $\begin{array}{l}\text { Areal extents of land-forest area according to the rate } \\
\text { of change of the year }\end{array}$ \\
\hline & conservation & $\begin{array}{l}\text { Habitats created by man presence, number and area } \\
\text { size }\end{array}$ \\
\hline
\end{tabular}


Table 6: Social well-being indicators. Source: adapted from [14-16].

\begin{tabular}{|c|c|c|}
\hline \multirow{14}{*}{$\begin{array}{c}\text { Social } \\
\text { welfare } \\
\text { of state }\end{array}$} & & Indicator \\
\hline & \multirow{3}{*}{ Employment/income } & $\begin{array}{l}\text { Turkey's national income per capita compared } \\
\text { to the average annual rate }\end{array}$ \\
\hline & & $\begin{array}{l}\text { Potential and actual activity and dependency } \\
\text { ratios }\end{array}$ \\
\hline & & Unemployment rate \\
\hline & \multirow{4}{*}{ Education/ housing } & Annual number of students per teacher \\
\hline & & Annual number of students per classroom \\
\hline & & Housing ownership \\
\hline & & Average household size \\
\hline & \multirow{4}{*}{ Health } & Average life time women/men \\
\hline & & Infant mortality rate \\
\hline & & Per capita public open space \\
\hline & & $\begin{array}{l}1000 \text { number of beds per person and the } \\
\text { changes in the last } 5 \text { years }\end{array}$ \\
\hline & Participation/governance & $\begin{array}{l}\text { Citizen participation in local government- } \\
\text { level meetings }\end{array}$ \\
\hline & Security & $\begin{array}{l}\text { Recorded crime rate compared to the average } \\
\text { percentage of Turkey }\end{array}$ \\
\hline
\end{tabular}

MAXQDA11 content in a digital environment for the analysis of qualitative data analysis program was used. Some of the voice-depth interviews remaining were recorded in writing. Under certain conditions groups responded to any digital distribution, of course the next step in the process of content analysis in order to keep the codes and categories had been created. For each query a separate codecategory system was established, after the recording a program is installed on the existing record in each issue code, for words that use, re-query performed, code, frequency and percentage distributions were reached. Collected under the same category, the percentage distribution of the code phrase for each category with the numerical findings had an accessed percentage, which is supported by the qualitative findings. As other questions were multiple choice and preferencerated questions, quantitative findings could be accessed directly as a result of the interview.

\section{Results}

As a result of the hypothesis originally postulated, namely; sustainable development in medium-sized cities of the land-use planning process parameters on the perception of local government officials responsible for the implementation level, expectations and initiatives that create barriers because of the subject, the accuracy has been reached. Results of the study discussed in the literature of information on keywords, the first phase of research in the set of indicators generated sustainable development plans for Nigde findings and from the in-depth interviews with the local management of the results obtained is given in relation to each other. 
Table 7: Results for "sustainability".

\begin{tabular}{|c|c|}
\hline Benchmark findings in the plan & The results from interviews \\
\hline $\begin{array}{l}\text { Nigde is within the boundaries of the plan } \\
\text { approved in } 20051 / 100.000 \text { The purpose of the } \\
\text { environmental plan "Targeted for the year } 2025 \\
\text { based on the principle of sustainable } \\
\text { development in planning, creating a liveable } \\
\text { environment social, cultural and historical } \\
\text { identity protection, environment and } \\
\text { development policies and sectoral development } \\
\text { objectives determined in accordance with the } \\
\text { scope of the planning principles to ensure } \\
\text { the healthy development and growth" [15] is in } \\
\text { the form When planning studies intended to } \\
\text { examine the province of Nigde digital and even } \\
\text { the lack of evidence of current land-use maps of } \\
\text { the city show that sustainable development is far } \\
\text { from ideal. }\end{array}$ & $\begin{array}{l}\text { In-depth interviews with local government } \\
\text { administrative officials - Sustainable urban } \\
\text { development in the connotation of the concept } \\
\text { of 'what are you?' In response to the question } \\
\text { category with } 33 \% \text { of the most cited response, } \\
\text { similar to that described in the literature in } \\
\text { general, the adequacy of natural resources has } \\
\text { been the identification of the category. } \\
\text { Therefore, knowledge of the authorities on the } \\
\text { subject in general can be said that. However, } \\
\text { the city's sustainability plan, according to the } \\
\text { findings in the reports on the relations with } \\
\text { the only purpose of the plan, is to stay in the } \\
\text { descriptions. }\end{array}$ \\
\hline
\end{tabular}

Table 8: Findings for the "land-use planning".

\begin{tabular}{|c|c|}
\hline Benchmark findings in the plan & The results from interviews \\
\hline $\begin{array}{l}\text { In the literature, according to the definition of } \\
\text { land-use planning in the planning process legally } \\
\text { entering our country does not have a definition. } \\
\text { However, in content, more developed in terms of } \\
\text { social issues, with a zoning plan process can be } \\
\text { said to be similar. However, in this context, for } \\
\text { Nigde, there is not a current zoning plan. The } \\
\text { most recent plan for the entire city in 1981, made } \\
\text { changes to the present have been applied with } \\
\text { modifications (Nigde Municipality, 2011). } \\
\text { Therefore, from a comprehensive planning } \\
\text { approach in Nigde, contemporary land use } \\
\text { planning and its components can be said that far } \\
\text { from.. }\end{array}$ & $\begin{array}{l}\text { Located in the literature in the context of the } \\
\text { identification component, similar to } 39 \% \text { with } \\
\text { the majority of the administrative authorities of } \\
\text { the local government land-use planning, the } \\
\text { definition of 'site selection of urban functions' } \\
\text { has been set out. Therefore, it cannot be said to } \\
\text { be unconscious. Findings on the planning for } \\
\text { Nigde indicate that there is a current plan; the } \\
\text { theme of the interview remarks on the set of } \\
\text { indicators for Nigde. When asked to rank the } \\
\text { importance, a land-use ratio of } 2.6 \% \text { was selected } \\
\text { for the most trivial issues. }\end{array}$ \\
\hline
\end{tabular}

Table 9: Findings for "indicator set".

\begin{tabular}{|l|l|}
\hline \multicolumn{1}{|c|}{ Benchmark findings in the plan } & \multicolumn{1}{c|}{ The results from interviews } \\
\hline 19 of 63 indicators of six main themes \\
$\begin{array}{l}\text { connected to the supply problems, due to the } \\
\text { inaccessibility of data; the data is accessible to } \\
\text { the date of the local government's planning } \\
\text { process and consists of different stages of } \\
\text { prepared a questionnaire with questions set of } \\
\text { indicators in the 8th and 9th of the main themes } \\
\text { of Nigde, which is important for the work which } \\
\text { is done for/was asked to do. With } 42 \% \text { and } 21 \%, \\
\text { it important enough. Plans are not accessible to } \\
\text { with environmental health and waste energy } \\
\text { when selecting the most important issues, and } \\
\text { semi-structured in-depth interviews with the } \\
\text { themes in this indicator information from the } \\
\text { authorities tried to take out. }\end{array}$ & $\begin{array}{l}\text { social well-being studied for } 19 \% \text { and } 18 \% \text { with } \\
\text { the ideas on the subject are reported to have. } \\
\text { operation of the planning system, goals and } \\
\text { requests between applications reveal that they } \\
\text { are uncoordinated. }\end{array}$ \\
\hline
\end{tabular}


Table 10: Findings for "participation/governance".

\begin{tabular}{|l|l|}
\hline \multicolumn{1}{|c|}{ Benchmark findings in the plan } & \multicolumn{1}{c|}{ The results from interviews } \\
\hline $\begin{array}{l}\text { Social well-being on the set of sustainable } \\
\text { development indicators located under the theme } \\
\text { of participation/governance indicators have not } \\
\text { benefited from working for any inventory data } \\
\text { access that has been achieved. }\end{array}$ & $\begin{array}{l}\text { The results indicate that in-depth interviews } \\
\text { with administration officials had a majority of } \\
40 \% \text { participation/governance indicators for } \\
\text { Nigde } 5 \text { point Likert scale ranking "somewhat } \\
\text { important" respectively. However, as stated in } \\
\text { the literature, which is key to the sustainability } \\
\text { of land-use planning in the planning process. } \\
\text { This is based on dialogue as the most important } \\
\text { feature of the development. In this context, the } \\
\text { understanding of the administrative authorities } \\
\text { of the land-use planning can be said that it is far } \\
\text { from sustainable. }\end{array}$ \\
\hline
\end{tabular}

\section{Discussion and conclusions}

The findings obtained in this study support the hypothesis. Nigde was examined in the case of medium-sized city's local government, land-use planning and sustainable development indicators in the process. However, they still cannot grasp the full significance of the difficulties of implementing this system.

The main problem of urban living, at the source, is the "non-identity" problem that exists. In line with the vision of the city, it cannot create its own identity, which therefore, making it active potentially, should give priority to solving these problems. This directly affects the city's economy. This causes a problem of identity. These are the most important elements that shape the city's economy, which is located in the initiative of the local government planning tool. This relationship can be understood from the spiral of everything related to the sustainable urban development, urban planning and process of local the government administration which is based on this success.

From the first step to the last of the study, at each stage; the upper scale of the local government sub-scale urban planning in sustainable urban development authority and responsibility on behalf of the importance of the task emerged again. Medium-sized cities, urban planning approach applied in the sustainability of land-use planning, which can be directly attributable to a process, is noteworthy. This process; working a document without a lot of input, dialogue-driven, employee multi-themed in itself, repeating is a process, not only legal background wallpaper. Therefore, for local governments, they need to be more responsible in the process and act as the coordinator. As a result of the findings reached, the administration of local government in the city from every angle shows it is weak. In this context, for a medium-sized city of Nigde, new technical, social, administrative structures and the planning process as needed on behalf of the updates is what their system really needs. 


\section{References}

[1] World Bank (WB) Officially web site, http://einstitute.worldbank.org/ ei/course/sustainable-urban-land-use-planning (accessed 09.05.13).

[2] Food and Agriculture Organization of the United Nations (FAO), official website, http://www.fao.org/docrep/t0715e/t0715e02.htm\#chapterlnature andscope, 1993 (accessed 10.09.12).

[3] Chapin, S. \& Kaiser, E., Urban Land Use Planning. University of Illinois Press. 1985.

[4] Godschalk, D., Land Use Planning Challenges: Coping with Conflicts in Visions of Sustainable. Journal of the American Planning Association, 70(1), 5-13, 2004.

[5] Zimmermann, W., Land Use Planning Methods, Strategies and Tools, Deutsche Gesellschaft für Technische Zusammenarbeit, 1999.

[6] Chapin, S. \& Kaiser, E. Urban Land Use Planning. University of Illinois Press, 1985.

[7] Weilanda, U., Indicators for Sustainable Land Use Management in Santiago De Chile. Ecological Indicators, 2011.

[8] Wehrmann, B., Land Use Planning Concept, Tools and Applications. Eschborn/Germany: Deutsche Gesellschaft für Internationale Zusammenarbeit (GIZ) GMBH Division Agriculture, Fisheries and Food Sector Project Land Policy and Land Management, 2011.

[9] Yazar, H. "21. Yüzyılda Orta Ölçekli Kentler ve Kent Planlama Yaklaşımı”, Dönüşen Kentler ve Değişen Yerel Yönetimler (Ed.) Fatma Neval Genç, Abdullah Yılmaz ve Hüseyin Özgür, Gazi Kitabevi, Ankara, 90-122, 2008.

[10] The Mid-Sized City: Exploring It's Unique Place in Urban Policy, A Summary of the Rochester Conservation on Mid-Size Cities, November, s12, Rochester, USA, http://ivable.org/storage/documents/reports/ Other/The_MidSized_City_Exploring_its_Unique_Place_in_Urban_Polic y.pdf, 2002 (accessed 28.11.13).

[11] Özgür, H. "Türkiye'de Orta Ölçekli Kentsel Alanların Yönetimi Sorunu", Yerel Yönetimler Üzerine Güncel Yazılar-1: Reform, (Ed.) Hüseyin Özgür ve Muhammet Kösecik, Nobel Yayın Dağıtım, Ankara, 471-498, 2005.

[12] http://baxterwoodman.com/documents/Report.pdf (accessed 25.11.13).

[13] Strauss, A. \& Corbin, J., Basics of Qualitative Research: Techniques and Procedures for Developing Grounded Theory. London, UK: Sage Publications Inc. http://www.stibamalang.ac.id/uploadbank/pustaka/RM/ BASIC\%20OF\%20QUALITATIVE\%20RESEARCH.pdf_1998.

[14] World Bank, official web site. http://data.worldbank.org/indicator (accessed 10.02.2014).

[15] Fraser Basin Council, Sustainability Snapshot 2010 Working Together in The Lower Mainland. Vancouver: Fraser Basin Press, 2010.

[16] Organisation for Economic Co-operation and Development (OECD), OECD Sustainable Development Indicators; Sustainable Development Critical Issues. Paris: OECD, 2001. 
[17] Dogan, M. Nigde Agricultural Master Plan. Nigde: Nigde provincial Directorate of Agriculture Press, 2002.

[18] Ranhagen, U. \& Groth, K., The Symbio City Approach, A Conceptual Framework for Sustainable Urban Development. Stockholm, Sweden. http://www.symbiocity.org/PublicDownloads/The\%20SymbioCity\%20Ap proach $/ \mathrm{SCA} \% 20$ full\%20version $\% 20(6,1 \% 20 \mathrm{Mb})$.pdf (accessed 10.01.13).

[19] Special Provincial Administration of Nigde, Plan and Report of 1/25.000 Scale Environmental Organization Plan, 2011. 